Article

\title{
Designing Thinning Operations in 2nd Age Class Pine Stands-Economic and Environmental Implications
}

\author{
Piotr S. Mederski ${ }^{1, *(1)}$, Rachele Venanzi ${ }^{2}$, Mariusz Bembenek ${ }^{1}$, Zbigniew Karaszewski $^{3}$, \\ Martyna Rosińska ${ }^{1}$, Zenon Pilarek ${ }^{4}$, Irene Luchenti ${ }^{2}$ and Michał Surus ${ }^{1}$ \\ 1 Faculty of Forestry, Department of Forest Utilisation, Poznań University of Life Sciences (PULS), \\ ul. Wojska Polskiego 71A, 60-625 Poznań, Poland; mariusz.bembenek@up.poznan.pl (M.B.); \\ martyna.rosinska@up.poznan.pl (M.R.); surus.michal@gmail.com (M.S.) \\ 2 Department of Agriculture and Forest Sciences (DAFNE), Tuscia University, Via S. Camillo de Lellis, \\ 01100 Viterbo, Italy; venanzi@unitus.it (R.V.); ireneluchenti@hotmail.it (I.L.) \\ 3 Department of Wood Investigation and Application, Wood Technology Institute, ul. Winiarska 1, \\ 60-654 Poznań, Poland; z_karaszewski@itd.poznan.pl \\ 4 Faculty of Forestry, Department of Forest Technology, Poznań University of Life Sciences (PULS), \\ ul. Wojska Polskiego 71C, 60-625 Poznań, Poland; zpilarek@up.poznan.pl \\ * Correspondence: piotr.mederski@up.poznan.pl; Tel.: +48-61-848-7761
}

Received: 28 May 2018; Accepted: 4 June 2018; Published: 7 June 2018

\begin{abstract}
The application of a harvester for thinning operations in young stands can pose several dilemmas. Firstly, the value of the timber obtained should be higher than the cost of the thinning operation-this is especially difficult with young stands, where the timber is of a small size and productivity is low. In addition, small harvesters used for thinning usually have short cranes, less than $10 \mathrm{~m}$ in length, which is rather impractical in stands where the distance between strip roads is a standard $20 \mathrm{~m}$. The aim of this research was to select the best mechanised thinning operation, taking into account economic suitability and some environmental aspects (damage to the remaining stand and density of strip roads). The research was carried out in a 31-year-old pine stand (11.27 ha) in which three different harvester thinning (T) operations were designed: TM1) with midfield and one harvester pass, TM2) with midfield and two harvester passes and TWM) without midfield and one harvester pass. In all the proposed operations, a Vimek $404 \mathrm{~T} 5$ harvester (with a $4.6 \mathrm{~m}$-long crane) and a Vimek 606 TT forwarder were used. The most economic operation was TWM, with a total cost of $€ 13.73 \mathrm{~m}^{-3}$, while TM1 was $13 \%$ more expensive at $€ 15.51 \mathrm{~m}^{-3}$. The lowest level of damage, $1.5 \%$, was recorded in TWM, while in TM1 the level was $2.1 \%$. The TWM operation required a net of strip roads twice as dense as in TM1. Taking into account all the analysed aspects, a thinning operation with midfield and one harvester pass is recommended when using the Vimek 404 T5 harvester and the Vimek 606 TT forwarder in the first thinning of a pine stand.
\end{abstract}

Keywords: early thinning; strip roads; productivity; costs; damage; Vimek

\section{Introduction}

The effective use of a mechanised thinning operation in a young pine stand is challenging from an economic perspective. When using a harvester and forwarder, it is best to start with the first thinning when the value of the timber obtained is higher than the cost of the thinning operation. However, this is especially difficult in young stands, where the timber is of a small size, as this may lead to low productivity. This results in the rare application of mechanised early thinnings, but there is also a growing interest in suitable mechanised silvicultural treatments in artificial ecosystems in Europe $[1,2]$. 
To obtain the best compromise between economic and ecological aspects, particularly in the first early thinning, geometrically selective thinning may be applied when possible, with respect to selective treatments when ecological aspects are of paramount importance [3,4].

In Central Europe, the first commercial thinning of pine (Pinus sylvestris L.) can be carried out in ca. 30-y.o. stands and the timber obtained is usually used in the pulp and paper industry or for chips as renewable energy biomass. Young stands ready for the first thinning need to be accessible for forest operation machines. To a certain degree, harvester parameters determine the distribution of strip roads in the forest. The crane length impacts on the distance between the strip roads, while the width of the harvester (but also of a forwarder) determines the width of the strip roads. In the majority of cases, the distance between strip roads is $20 \mathrm{~m}$ (measuring between the axis of the strip roads) and the width is approximately $4 \mathrm{~m}$. This is due to the fact that nowadays, harvester cranes are ca. $10 \mathrm{~m}$ in length and the machines themselves are no wider than ca $3 \mathrm{~m}$. However, some manufacturers of cut-to-length (CTL) technology may vary these measurements. Smaller harvesters can be equipped with cranes 4 to $6 \mathrm{~m}$ long and their width may be no bigger than $2 \mathrm{~m}$. Available early thinning machines of these sizes are manufactured, for example, by Vimek. Vimek harvesters are equipped with a $4.6 \mathrm{~m}$ long crane and the machine is $1.8 \mathrm{~m}$ wide. Forwarders have the same long crane and machine width. These parameters present obvious dilemmas when the first thinning is expected and new strip roads are planned. There are two solutions: (1) the establishment of strip roads with a distance of 9-10 m between them; or (2) a distance of $20 \mathrm{~m}$ between strip roads, but a 10-m-wide midfield in the middle, on which trees are cut with a chainsaw and felled towards the closest strip road [5]. Taking into account the two variants of the distance between strip roads, 10 or $20 \mathrm{~m}$, it was hypothesised that a greater distance would, in the end, give a higher productivity from harvester/forwarder application and consequently lead to lower costs. It was also hypothesised that the forwarder, in particular, would be more efficient due to a higher timber concentration after thinning, if the larger $20 \mathrm{~m}$ distance between strip roads was applied. It was also considered that there may be differences in the level of damage to the remaining trees on plots where the distance between the strip roads was 10 and $20 \mathrm{~m}$.

Therefore, the objective of this research was to analyse: (1) the productivity and costs of the Vimek harvester and forwarder in a very young pine stand undergoing its first commercial thinning with respect to different strip road design and machine application; (2) the level of tree damage due to the mechanised thinning operation on plots with a distance between strip roads of between 10 and $20 \mathrm{~m}$; and (3) the total area per hectare of the stand which needs to be excluded from production in order to establish strip roads.

\section{Materials and Methods}

The research was carried out in a 31-year-old pine (Pinus sylvestris L.) stand of 11.27 ha, in compartment $108 \mathrm{~h}$ in the North of Poland (Bobolice Forest District, Table 1). According to the forest inventory data from 2015 (year of thinning operation), the average DBH of pine was $13 \mathrm{~cm}$ and the mean height $11 \mathrm{~m}$. Silver birch (Betula pendula Roth) was also represented in the stand (10\%, Table 1) with the same age and mean $\mathrm{DBH}$, but with a slightly greater height of $12 \mathrm{~m}$.

Table 1. Stand characteristics before thinning; general forest inventory data valid on 1 Jan 2015.

\begin{tabular}{|c|c|c|c|c|c|c|c|c|}
\hline Com-Partment & Area, ha & Species & Share, $\%$ & Age, Years & DBH, Mean, cm & H, Mean, $\mathrm{m}$ & Stocking, $\mathrm{m}^{3} \mathrm{ha}^{-1}$ & Understorey Species \\
\hline \multirow{3}{*}{$108 \mathrm{~h}$} & 11.27 & pine & 90 & 31 & 13 & 11 & 137 & birch \\
\hline & & birch & 10 & 31 & 13 & 12 & 10 & spruce \\
\hline & & spruce & sporadically & - & & & & juniper \\
\hline
\end{tabular}

The species composition was enriched with sporadic appearances of spruce and larch. In addition, birch, spruce and juniper occurred intermittently in the understorey. The stocking of the main stand layer before thinning was $147 \mathrm{~m}^{3} \mathrm{ha}^{-1}$. This stocking was achieved after a late cleaning was carried out in 2003, as well as pre-commercial thinning in 2007, when strip roads were also established by 
removing one tree row every ca $20 \mathrm{~m}$. During the pre-commercial thinning, $160.85 \mathrm{~m}^{3}$ of energy wood was harvested (a maximum top diameter of $7 \mathrm{~cm}$ over bark) and $19.70 \mathrm{~m}^{3}$ of pulp wood (a minimum top diameter of $7 \mathrm{~cm}$ over bark).

In 2015, three different harvester thinning (T) operations were designed: TM1) with midfield and one harvester pass, TM2) with midfield and two harvester passes, and TWM) without midfield and one harvester pass (Figure 1).

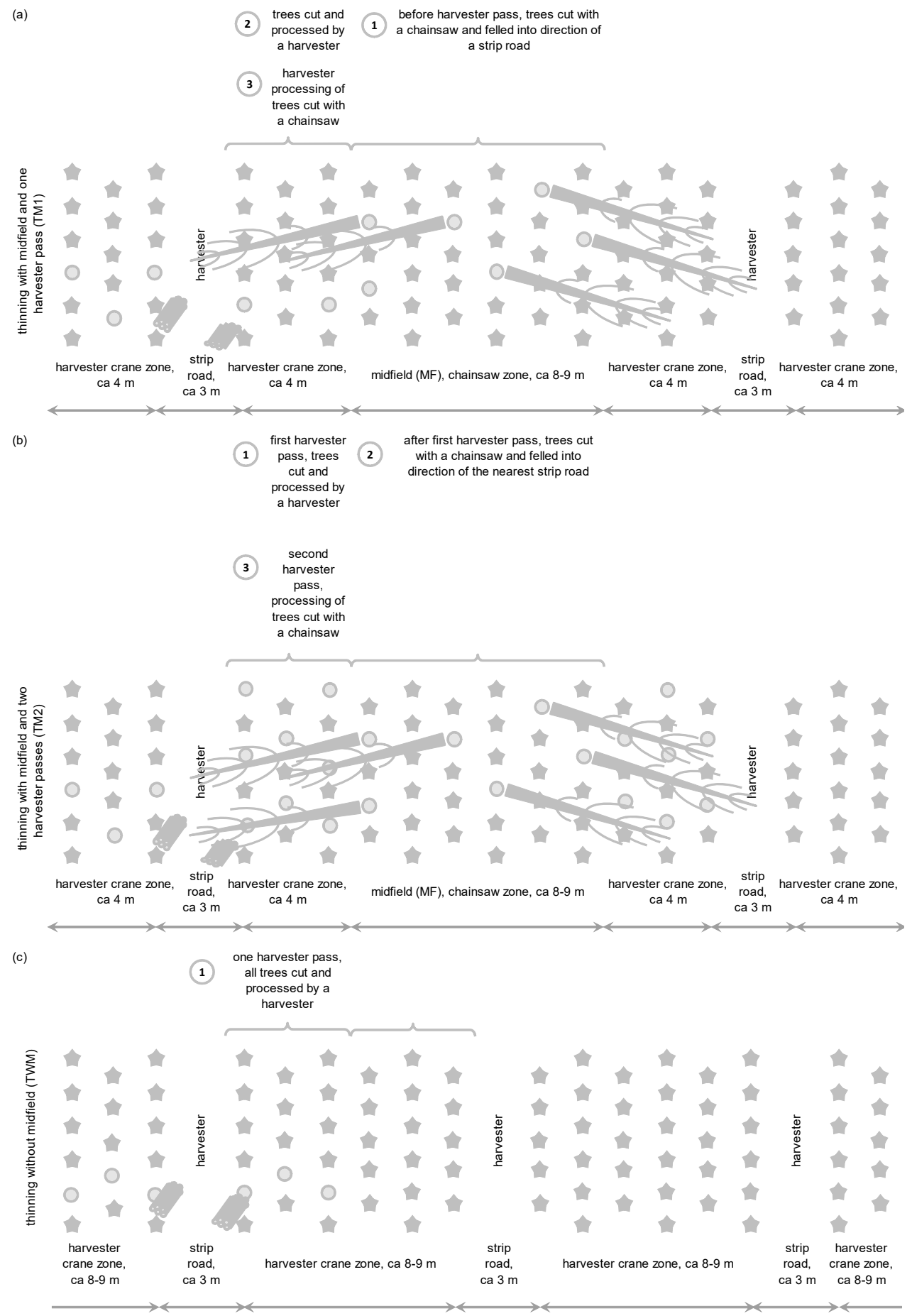

Figure 1. Design of analysed thinning operations: (a) Thinning with midfield and one harvester pass (TM1); (b) Thinning with midfield and two harvester passes (TM2); (c) Thinning without midfield (TWM). Distance between tree rows was from 1.4 to $1.6 \mathrm{~m}$. 
The thinning operations with midfield and without have been described in detail in previous research [5]. In TM1, the distance between the strip roads was ca $20 \mathrm{~m}$ (between the axis of the strip roads). In the first stage, on the midfield (a ca 8-9 m-wide zone between the strip roads), the trees were cut with a chainsaw and felled towards the nearest strip road. In stage two, the harvester cut the trees on a $4 \mathrm{~m}$-wide zone next to the strip road and processed them. Finally, in stage three (within the same pass), the harvester processed the trees cut by the chainsaw. In TM2, the distance between the strip roads was also ca $20 \mathrm{~m}$. In stage one, the harvester cut and processed the trees in a $4 \mathrm{~m}$-wide zone next to the strip road (as in step two in TM1). In stage two, the chainsaw operator felled the trees towards the nearest strip road. In stage three, in the second pass, the harvester processed the trees cut by the chainsaw. Finally, in TWM, the distance between the strip roads was ca 10-12 m; the harvester cut and processed the trees from the 4 m-wide zones next to the strip roads. In all the thinning operations, the strip roads were ca $3 \mathrm{~m}$ wide, established by removal of one tree row during pre-commercial thinning in 2007. The distance between the tree rows ranged from 1.4 to $1.6 \mathrm{~m}$.

Each thinning operation was carried out along two strip roads, which were ca $175 \mathrm{~m}$ long. In each type of operation, 20 sample plots were marked $(10 \mathrm{~m} \times 10 \mathrm{~m})$, on which all trees for harvesting were measured. The DBH was measured twice perpendicularly using a Haglöf Mantax Blue manual caliper (Haglöf Sweden AB, Långsele, Sweden), with an accuracy of $1 \mathrm{~mm}$, while the heights were measured using a Haglöf Vertex Laser height measurer (Haglöf Sweden AB, Långsele, Sweden), with an accuracy of $0.1 \mathrm{~m}$. The trees selected for harvesting in all the operations had a similar mean DBH and height with no statistically significant differences (Table 2 , K-W test, $p<0.05$ ).

Table 2. Characteristics of trees selected for thinning operations.

\begin{tabular}{|c|c|c|c|c|c|c|}
\hline Feature & TM1 DBH, cm & TM1 H, m & TM2 DBH, cm & TM2 H, m & TWM DBH, cm & TWM H, m \\
\hline Mean & $12.3^{\mathrm{a}}$ & $12.5^{\mathrm{a}}$ & $11.5^{\mathrm{a}}$ & $11.9^{\mathrm{a}}$ & $10.9^{a}$ & $11.8^{\mathrm{a}}$ \\
\hline Minimum & 7.0 & 7.8 & 7.0 & 6.3 & 7.0 & 8.2 \\
\hline Maximum & 25.0 & 17.8 & 24.0 & 15.8 & 23.0 & 16.4 \\
\hline SD & 3.9 & 1.8 & 3.9 & 2.0 & 3.4 & 1.7 \\
\hline $\mathrm{N}$ & 100 & 100 & 112 & 112 & 110 & 105 \\
\hline
\end{tabular}

Different letters next to mean values indicate statistically significant differences. DBH: diameter at breast height, $\mathrm{H}$ : height.

All the trees for harvesting were marked with individual numbers for further tree recognition during the time studies and further time analysis per one tree when possible: for harvester as well as for chainsaw felling. For forwarding, only general productivity was analysed in $\mathrm{m}^{3}$ per hour. For the harvesting, forwarding, and chainsaw felling, a time study was carried out with an accuracy of $1 \mathrm{~s}$. As the thinning operations were of a particular design, the typical categories of time were split up in order to determine the reasons for differences in productivities. For the harvester, three categories of time were distinguished: (A) preparation (tidying residues), machine moving, crane out, head positioning, felling; (B) delimbing and bucking; (C) delays. Time A was of particular interest, as it was hypothesised that it would be the longest in operation TM1, of medium duration in TM2, and the shortest in TWM. At the same time, it was presumed that time B would be the same in all three operations. Delay times were initially recorded, but eventually for the cost calculations, machine utilisation (MU) was considered more representative for machine use and chainsaw operator work. This decision was made for two reasons: (1) delay times were either accidental in this case study; or (2) compulsory in the harvesting and forwarding on account of the scheduled refuelling at the end of each strip road.

MU was obtained from engine working time (EWT), recorded by machine meter (total time from engine ignition until switch off). EWT was finally reduced by time of engine-idle speed time and time spent on machine relocation. Machine relocation on wheels (without a low-loading trailer) happened occasionally and was accepted up to ca $10 \mathrm{~km}$. Otherwise, a low-loading trailer was used, the costs of which were considered in suitable calculations. This reduction used for calculation of MU was based 
on the expert decision of the machine owner. EWT was taken as total hours from beginning of machine use until the day of analysis, divided by total number of shift hours in the respective period of time.

For forwarding, four time categories were considered: (A) driving empty; (B) driving and loading; (C) driving loaded; (D) unloading. It was expected that loading in TM1 and TM2 would be more effective than in TWM due to a higher timber concentration next to the strip roads. When forwarding, delay times were linked to refuelling after finishing extraction on one strip road. These breaks would not take place in a normal day shift; therefore MU was eventually considered, and it was obtained using the same methodological approach as in case of the harvester.

For the chainsaw operation, three time categories were applied: (A) walking from one tree to another; (B) felling; and (C) delays. It was hypothesised that felling would take less time in TM2 than in TM1, due to the opening up of the space between the trees by the harvester in TM2 (fewer hanging trees). Delay times were also recorded. Again, as it was a case study, in the final analysis, the average daily delay times were used to calculate the MU.

For the productivity and cost measurements, all the harvested trees were considered. In all the proposed operations, a Vimek 404 T5 harvester and a Vimek 606 TT forwarder were used (Table 3).

Table 3. Harvester and forwarder characteristics.

\begin{tabular}{ccc}
\hline Feature & Harvester Vimek 404 T5 & Forwarder 606 TT \\
\hline Weight, $\mathrm{kg}$ & 3800 & 2960 \\
Length, $\mathrm{m}$ & 3.35 & 6.20 \\
Width, $\mathrm{m}$ & 1.84 & 1.80 \\
Engine & CAT 2.2T & Kubota D 902-E \\
Engine power, $\mathrm{kW}$ & 44.7 & 18.0 \\
Crane/length, $\mathrm{m}$ & Mowi 2046/4.6 m & Mowi 2046/4.6 m \\
Head/max. diameter & Keto Forst Silver $/ 30 \mathrm{~cm}$ & - \\
Lifting capacity, kg & - & 300 \\
Loading capacity, kg & - & 3000 \\
Tyres, front & Mitas 405/70-24 & Mitas 405/70-24 \\
Tyres, rear & Mitas 405/70-24 & Mitas 400/60-15.5 \\
\hline
\end{tabular}

Harvesting was carried out by a 43-year-old operator, with two years of experience working on harvesters. The forwarder operator was 27 years old and had two years' work experience. He also carried out the manual felling of trees, of which he had six years' experience.

Both the operators were instructed before thinning. Thinnings with midfield (TM1 and TM2) were new to the harvester operator, therefore several trees were felled by chainsaw and later pulled and processed by the harvester in order to learn the process before the research study began.

The length of all the logs was $2.55 \mathrm{~m}$, and two types of assortments were prepared: pulp wood, thicker logs from the bottom parts of trees, and energy wood, thinner (maximum $7 \mathrm{~cm}$ over bark) from the tops of trees. The harvested logs were processed at the side of a strip road for further forwarding. Each pile of logs consisted of only one type of assortment. Bottom logs-pulp wood-from a few trees were put in one pile, top logs-energy wood-also from a few trees were disposed of in another pile. This was done in order to boost forwarder efficiency. Consequently, the volume and productivity of each thinning operation was calculated as a mean for each machine. After forwarding, separate piles of timber were made for each operation. The width, height and length of the piles were measured and suitable official conversion factors were used to calculate the timber volume under bark.

The volume of merchantable timber of the standing trees was also not used in the further calculation of productivity curves, as the harvester usually finished processing at a smaller diameter than $7 \mathrm{~cm}$ over bark. Therefore, it was decided that the mean harvester and forwarder productivities should be specified, and these were then used for the cost calculations.

All costs linked to machine use were obtained from the machine owner as they were recorded in the company's books (Table 4). The diesel consumption of the harvester and forwarder was measured 
at the end of each strip road. The tanks were full before the operation started and after each strip road was finished, both the harvester and forwarder were refuelled. The volume of added diesel was measured using a vessel with a volume accuracy of $0.1 \mathrm{~L}$. The chainsaw fuel and oil tanks were refilled when necessary (when the petrol finished), for which a vessel with an accuracy of $0.1 \mathrm{~L}$ was used.

Table 4. General data for cost calculations.

\begin{tabular}{lccc}
\hline \multicolumn{1}{c}{ Feature } & Harvester & Forwarder & Husqvarna 346 XP \\
\hline Initial investment, $€$ & 229,848 & 125,134 & 476 \\
Economic life, years & 10 & 10 & 3 \\
Salvage value $(10 \%), €$ & 22,985 & 12,513 & 48 \\
Fuel price, $€ 1^{-1}$ & 1.09 & 1.09 & 1.20 \\
Number of working days per year & 242 & 242 & 242 \\
Number of working hours per day & 8 & 8 & 8 \\
Machine utilisation time, h year ${ }^{-1}$ & 1800 & 1600 & - \\
Machine utilisation time after reduction, h year ${ }^{-1}$ & 1500 & 1400 & - \\
Machine utilisation & 0.775 & 0.723 & 0.813 \\
\hline Monthly: & & & \\
Insurance, $€$ & 83.12 & 49.57 & - \\
Garage, $€$ & 3.46 & 3.46 & - \\
Lubricants, $€$ & 119.04 & 17.89 & 54,56 \\
Repair and spare parts, $€$ & 215.51 & 75.51 & 14.43 \\
Relocation costs, $€$ & 63.90 & 63.90 & - \\
Labour costs (wages, incl. all costs), $€$ & 2311.69 & 1728.57 & 1330.00 \\
\hline
\end{tabular}

Stand damage was measured on 10 sample plots in each thinning operation. Stand damage (expressed in \%) was measured on the 10 sample plots used in each thinning operation. Data collection was carried out according to a design-based approach and a statistical method in order to overcome possible pseudoreplication problems [6]. The number of trees with damage (partial bark removal) as proposed by Picchio et al. [7], was recorded as the number of trees with damage against all the trees on the sample plots.

The strip road area was calculated per 1 ha. The strip road width multiplied by total length on 1 ha was calculated and cover was expressed in \% of area excluded from forest production.

To compare the data sets obtained from each thinning operation, the Mann-Whitney U test was applied with $p<0.05$ or Kruskal-Wallis test (for more than two independent measures) with $p<0.05$.

\section{Results}

\subsection{Productivity and Costs}

The highest mean thinning operation productivity, $4.83 \mathrm{~m}^{3} \mathrm{PMH}^{-1}$, was in TM1, where the distance between the strip roads was ca $20 \mathrm{~m}$ and one harvester pass was needed (Table 5). In the TM2 and TWM operations, the mean productivity for both machines, harvester and forwarder, was 4.55 and $4.50 \mathrm{~m}^{3} \mathrm{PMH}^{-1}$, respectively. The harvester was the most efficient in the operation without midfield, where the distance between the strip roads was only ca $10 \mathrm{~m}$. In contrast, forwarder productivity in TWM was the lowest and amounted to $4.33 \mathrm{~m}^{3} \mathrm{PMH}^{-1}$. Forwarder productivity in the operations with midfield was similar: 5.25 and $5.35 \mathrm{~m}^{3} \mathrm{PMH}^{-1}$ in TM1 and TM2, respectively. Unfortunately, TM1 and TM2 were 13\% and 23\% more expensive (respectively) than the TWM operation.

The cost of chainsaw use made the operations with midfield more expensive. Fuel consumption (diesel) also had an impact on the lowest cost of harvester use in the operation without midfield, where only $0.46 \mathrm{~L}$ per $1 \mathrm{~m}^{3}$ of harvested timber was used (Table 6). 
Table 5. Productivity and cost of thinning operations.

\begin{tabular}{cccc}
\hline Feature & TM1 & TM2 & TWM \\
\hline Harvester productivity, $\mathrm{m}^{3} \mathrm{PMH}^{-1}$ & 4.42 & 3.74 & 4.67 \\
Forwarder productivity, $\mathrm{m}^{3} \mathrm{PMH}^{-1}$ & 5.25 & 5.35 & 4.33 \\
Productivity of thinning, $\mathrm{m}^{3} \mathrm{PMH}^{-1}$ & 4.83 & 4.55 & 4.50 \\
Harvester costs, $€ \mathrm{~m}^{-3}$ & 8.83 & 10.34 & 7.89 \\
Forwarder costs, $€ \mathrm{~m}^{-3}$ & 4.80 & 4.69 & 5.84 \\
Chainsaw felling costs, $€ \mathrm{~m}^{-3}$ & 1.88 & 1.88 & - \\
Costs of thinning, $€ \mathrm{~m}^{-3}$ & 15.51 & 16.91 & 13.73 \\
\hline
\end{tabular}

Table 6. Fuel consumption by Vimek 404 T5 harvester, Vimek 606 TT forwarder, Husqvarna 346 XP.

\begin{tabular}{cccc}
\hline Feature & TM1 & TM2 & TWM \\
\hline Harvester diesel consumption, $\mathrm{L} \mathrm{m}^{-3}$ & 0.94 & 1.02 & 0.46 \\
Forwarder diesel consumption, $\mathrm{L} \mathrm{m}^{-3}$ & 0.31 & 0.30 & 0.40 \\
Chainsaw petrol consumption, $\mathrm{L} \mathrm{m}^{-3}$ & 0.11 & 0.08 & - \\
\hline
\end{tabular}

Diesel consumption by the forwarder was much lower in the operations with midfield in comparison with the harvester. It was also recorded that fuel use in the forwarding without midfield was ca $33 \%$ bigger than in the operations with midfield. Petrol consumption by chainsaw was low, ca $0.1 \mathrm{~L}$ per $\mathrm{m}^{3}$ of felled trees, as delimbing and bucking were carried out by the harvester.

\subsection{Harvesting Time Consumption}

Considering effective time without delays, more time was needed for one tree in operations with midfield: 43 and $48 \mathrm{~s}$ in TM1 and TM2 respectively. The shortest time was observed in TWM: $38 \mathrm{~s}$ per tree (Table 7).

Table 7. Harvester time consumption per one tree; results of Mann-Whitney U test and descriptive statistics of time categories.

\begin{tabular}{ccccccc}
\hline Feature & \multicolumn{2}{c}{ TM1 } & \multicolumn{2}{c}{ TM2 } & \multicolumn{2}{c}{ TWM } \\
\hline Time category & A & B & A & B & A & B \\
Mean (s) & $26^{\mathrm{a}}$ & $17^{\mathrm{a}}$ & $30^{\mathrm{b}}$ & $18^{\mathrm{a}, \mathrm{b}}$ & $23^{\mathrm{a}}$ & $15^{\mathrm{b}}$ \\
Min. (s) & 7 & 2 & 6 & 5 & 9 & 3 \\
Max. (s) & 72 & 81 & 77 & 92 & 57 & 69 \\
SD & 13 & 12 & 14 & 13 & 10 & 10 \\
N & 94 & 94 & 97 & 97 & 104 & 105 \\
\hline
\end{tabular}

Different letters next to mean values indicate statistically significant differences. TM1-thinning operation with midfield and one harvester pass; TM2 — thinning operation with midfield and two harvester passes; TWM—thinning without midfield. Time categories: A: Preparation (tidying residues), machine moving, crane out, head positioning, felling; B: Delimbing and bucking.

Processing time (B: Delimbing and bucking) was similar in all operations, although there was a statistically significant difference between the trees processed in TM1 and TWM. There was also the expected difference between the operations in time of tree preparation (A): More time was needed in operations with midfield in comparison with TWM (Table 7).

Tree chainsaw felling was more time consuming in the operation with one harvester pass, where $43 \mathrm{~s}$ were needed for one tree. In TM2, trees were felled after the first harvester pass, and only $24 \mathrm{~s}$ per tree was needed on average (Table 8). The time spent by the chainsaw operator moving from one tree to another was twice as long in TM1 as in TM2. These differences were statistically significant. The mean time of felling per tree was 64\% longer in TM1 than in TM2 (Table 8), and that difference was also statistically significant. 
Table 8. Chainsaw operator time consumption per tree; Mann-Whitney U test and descriptive statistics of time categories.

\begin{tabular}{ccccccc}
\hline Feature & \multicolumn{3}{c}{ Chainsaw Operator, TM1 } & \multicolumn{3}{c}{ Chainsaw Operator, TM2 } \\
\hline Time Category & A, $\mathbf{s}$ & $\mathbf{B}, \mathbf{s}$ & $\mathbf{C}, \mathbf{m i n} . \mathbf{s}$ & $\mathbf{A}, \mathbf{s}$ & $\mathbf{B}, \mathbf{s}$ & C, min.s \\
\hline Mean & $20^{\text {a }}$ & $23^{\text {a }}$ & 20.11 & $10^{\mathrm{b}}$ & $14^{\mathrm{b}}$ & 18.12 \\
Minimum & 3 & 4 & 13.41 & 3 & 3 & 12.08 \\
Maximum & 60 & 70 & 26.40 & 64 & 67 & 24.15 \\
Standard deviation & 15 & 16 & - & 10 & 12 & - \\
N & 43 & 43 & 2 & 50 & 50 & 2 \\
\hline
\end{tabular}

Different letters next to mean values indicate statistically significant differences. TM1—thinning operation with midfield and one harvester pass; TM2 - thinning operation with midfield and two harvester passes. Time categories: A: preparation (tidying residues), machine moving, crane out, head positioning, felling; B: delimbing and bucking; C: delays.

Delay times occurred at regular intervals and they were linked with chainsaw refuelling. Each break was ca $20 \mathrm{~min}$ and there were two breaks in each operation with midfield.

\subsection{Damage to the Remaining Stand}

Recorded damage was very low. On the 10 sample plots in each operation, approximately $2 \%$ of the trees had partial bark removal (Table 9). The least frequent damage, 1.5\% of trees, was observed in TWM, where a chainsaw was not used and the trees were not pulled from midfield by a harvester.

Table 9. Damage to remaining stand.

\begin{tabular}{cccc}
\hline Feature & TM1 & TM2 & TWM \\
\hline Number of trees with damage & 3 & 3 & 2 \\
Total number of trees & 142 & 138 & 130 \\
Share of trees with damage, $\%$ & 2.1 & 2.2 & 1.5 \\
\hline
\end{tabular}

A similar level of damage (2\%) was found in the thinning operations with midfield. Damage was observed only on a few sample plots.

\subsection{Strip Road Area}

As initially designed, TM1 and TM2 had a thinner network of strip roads, the distance between them being $20 \mathrm{~m}$. In such a configuration, the area needed for strip roads only amounted to $15 \%$ (Table 10). Twice as many strip roads were needed when TWM was proposed, and the total area excluded from production was $30 \%$.

Table 10. Strip road area, calculations per one hectare.

\begin{tabular}{cccc}
\hline Strip Road Detail & TM1 & TM2 & TWM \\
\hline Number of strip roads & 5 & 5 & 10 \\
Width, $\mathrm{m}$ & 3 & 3 & 3 \\
Distance between strip roads, $\mathrm{m}$ & 20 & 20 & 10 \\
Total length, $\mathrm{m}$ & 500 & 500 & 1000 \\
Area, $\%$ & 15 & 15 & 30 \\
\hline
\end{tabular}

\section{Discussion}

Obtaining satisfactory thinning operation production rates in young stands is difficult. Small tree sizes have the biggest impact on lower productivity [8,9], which also leads to higher costs for the whole operation [5]. In the presented research, the configuration of the strip road network was considered, which is mainly dependent on machine parameters and harvester crane reach. Smaller machines are expected to be used in younger stands, where thinning is necessary [10]. Smaller machines are also 
cheaper and cost less to use due to their lower fuel consumption [5]. The option presented of the Vimek harvester and forwarder was a good economic solution for small-size tree harvesting.

The economic assessment of the three different thinning operations showed that the cheapest option required a dense network of strip roads in the stand. However, the cheapest option contrasts with the long-term economic benefits from stand utilisation. Excluding 30\% of the land from further stand production is another cost to be borne by the forest owner.

Thinning with midfield is more difficult to manage. The chainsaw operator has to control the width of the midfield zone between two strip roads, which creates delays in tree felling. Additionally, the trees need to be felled in the direction of the nearest strip road. To avoid delays due to chainsaw operator hesitations, a thinning operation with two harvester passes was proposed. In TM2, after the first harvester pass and the felling of the trees next to the strip road, the midfield zone was visible for the chainsaw operator, and it was also easier to fell trees into the area next to the strip road, where thinning had already been carried out. However, both harvester passes cost $23 \%$ more than the cheapest option, TWM.

Timber harvesting with midfield is a known solution, described earlier in pine stands by Mederski [5]. In that study from the previous decade, a midfield was used in older stands of 3rd and 4th age classes, and thinning with midfield was the most economical. The productivities achieved at that time, more than a decade ago, were generally lower when compared to the harvesting nowadays, where in thinning operations approximately $20 \mathrm{~m}^{3} \mathrm{PMH}^{-1}$ is achieved [8,9]. In this context of highly productive thinning operations, the use of a chainsaw is an unwanted necessity. The proposed thinning operations with midfield make it possible to keep a standard distance between the strip roads thanks to the additional use of the chainsaw. However, it would be more convenient if small harvesters were developed with longer cranes for early thinnings.

A forest owner is interested in the best possible land use for production, and from the three different harvester operations presented, the one with midfield (TM1) would be in their best interest. In TM1, only $15 \%$ of the area was used for strip roads. The cost of the whole TM1 operation was $13 \%$ higher, although more trees (15\% extra forest area) were saved in the stand for future production. If this slightly higher cost of the thinning operation can be accepted, strip roads of regular density (20 m apart) will stay for the next thinning, when in the future a bigger harvester with a $10 \mathrm{~m}$-long crane will probably be used for late thinning.

In general, the productivities and costs achieved for these small machines should be considered satisfactory and similar to those achieved in other studies [11,12]. It was expected that, in particular, the forwarder productivity would be higher in the midfield operations due to a higher timber concentration [13] in comparison with TWM. Higher productivities in thinnings with midfield were achieved in previous studies using a Vimek forwarder [5], but these were in older pine stands. Bigger trees positively impact the productivities of both harvesters and forwarders $[8,9,13,14]$, although fork trees [15], tree sizes which are too large [16], or bigger slopes [17] lower the productivity of a harvester considerably.

A wider distance between strip roads allows for a bigger concentration of timber, which impacts positively on forwarding efficiency $[5,13]$. It was also expected that harvester productivity would be the highest in TWM: in this operation, the time for tree pulling from the stand was excluded, which made harvesting more efficient. However, it has to be pointed out that thinning with midfield was provided as an experimental case study and the harvester operator did not have experience in that type of operation (except a short training session on a few trees). Therefore, it may be expected that there is still potential to obtain higher productivities in this operation.

Harvester time consumption was the shortest when TWM was applied. This was expected as the time-consuming process of pulling trees from midfield was only in TM1 and TM2. Considering the processing time (delimbing and bucking), it was similar in all operations, although there was a statistically significant difference between TM2 and TWM. This was rather accidental, as there was no reason why those times should be different. In contrast, the time of preparation (A) was the shortest in 
TWM, which was expected as extra time was needed for tree pulling in the thinning with midfield. Additionally, the difference in time A was statistically significant when comparing TM2 and TWM (but again not in a comparison between TM1 and TWM).

Chainsaw felling time per tree was much shorter in TM2 due to the open space next to the strip roads after the first harvester pass (fewer hanging trees). Additionally, the time spent by the chainsaw operator moving from one tree to another (time A) was shorter in TM2. This was also expected as after the first harvester pass, the chainsaw operator had a clear view of which trees belonged to the midfield area.

An important aspect of the presented research is that the different thinning options of the Vimek harvester and forwarder are proposed with economic and environmental consequences-the cost and stand preparation with strip roads. Indeed, the cheapest harvesting option in this case was not the best one, because in comparison with TM1, a further 15\% of forest area (another tree row at this stage of stand development) needed to be excluded from production to create strip roads (Table 8). The loss in the future production of wood in that removed tree row is in fact much more expensive than the saved ca $€ 2$ in one thinning operation. Strip roads every $10 \mathrm{~m}$ in the stand would also be difficult to accept in relation to ecological aspects. It is also worth mentioning that in the next thinning (older stand), a bigger harvester may be used with a 10-m-long crane and strip roads every $10 \mathrm{~m}$ may not be necessary any longer.

When a mechanised thinning operation is used, the network of strip roads has a direct impact on soil compaction. TWM had double the area used for strip roads (every $10 \mathrm{~m}$ ) in comparison with TM1 or TM2 (every $20 \mathrm{~m}$ ). Consequently, a bigger area in TWM (30\% of the stand area) was under the pressure of machine wheels. This is more than the area affected by the skidder, where ca. $18 \%$ of the stand area can be disturbed [18], unless winching is used with a tractor in a coppice stand, which may affect a very small area of the stand (3-4\%) [19].

Soil compaction caused by a forwarder may be more severe [20], which may lead to a slower early growth of seedlings [21]. Forest machines, and especially fully-loaded forwarders, cause unwanted soil disturbances [22], which is usually more intensive in older stands, where trees of bigger dimensions are extracted [23].

Damage to the remaining stand was very low-only 1 to $2 \%$ of the trees were injured. This was comparable to the low-level damage characteristic for winching (especially with a snatch block) [24]. Otherwise, when the short wood system is used, a higher level of damage can be observed [25,26]. It was expected that in the thinning operations with midfield (with a larger distance between the strip roads), the level of damage would be higher, and it was. However, overall, only a few trees with bark damage were found on the sample plots. In operations with midfield, trees cut with a chainsaw have to be pulled afterwards by a harvester for processing-pulling trees creates additional opportunities for the remaining stands to be damaged. However, in 31-year-old pine stands, trees are of small sizes (Table 1), and even though they are pulled between other trees, it does not necessarily mean that damage will be done. The extraction of bigger trees in older stands may lead to a higher probability of damage to the remaining trees, but not necessarily in the short wood system [27]. In the presented study, only a few trees had damage, and besides, there is still the chance of the healing and overgrowth of wounds [28].

An interesting aspect of the presented research was fuel consumption. When the harvester was used in operations with midfield, a greater use of diesel was recorded. This was a natural consequence of the additional work-pulling the felled trees for processing. At the same time, a higher diesel consumption was noted when the forwarding was carried out in TWM. Again, the smaller timber concentration next to the strip road led to lower forwarder productivity and eventually to higher fuel use.

Considering more aspects (apart from the economic one) in thinning operations is vital in order to select the right forest operation method. Current trends show that combining economic and ecological issues is not enough, and more aspects should be considered: ergonomic, social and product quality [29]. This is very important considering the recent dynamic growth in mechanised forest operations [30-32]. 


\section{Conclusions}

The use of the Vimek 404 harvester and Vimek 606 TT forwarder in the 31-year-old pine stand had satisfactory productivity and acceptable costs. Three different thinning operations were proposed for these machines requiring different networks of strip roads. Taking into consideration all the aspects presented here (costs, damage to the remaining stand and density of strip roads), the best solution for the forest owner is to use the thinning operation with midfield and one harvester pass. Although this operation may require higher costs of ca $13 \%$ for the whole operation, a reasonable strip road density will exist in the stand. In addition, with this operation, $15 \%$ of the stand area was saved for timber production for the next decades. Overall, the level of damage was very low in all cases. However, when thinning with midfield was applied, about $2 \%$ of the trees were damaged.

Author Contributions: P.S.M., M.B. and Z.K. conceived and designed the experiments; P.S.M., M.S. and M.R. performed the experiments; M.S. and P.S.M. analysed the data; P.S.M. wrote the paper, R.V., Z.P. and I.L. contributed to the writing of the paper.

Funding: The research was completed with financial support from Ministry of Science and Higher Education, granted to the Department of Forest Utilisation (PULS) for the year 2015.

Acknowledgments: We would like to thank Adam Potocki, the manager of Bobolice Forest District for support during the research and for access to the selected stand. Thank you to Waldemar Winkowski, forest entrepreneur, who put his machines at our disposal, and allowed us access to his financial records. Finally, we would like to thank Fabian Winkowski, harvester operator, and Przemysław Kowalczyk, forwarder and chainsaw operator, for their good cooperation in completing the thinning operations.

Conflicts of Interest: The authors declare no conflict of interest. The founding sponsors had no role in the design of the study; in the collection, analyses, or interpretation of data; in the writing of the manuscript, and in the decision to publish the results.

\section{References}

1. Emer, B.; Grigolato, S.; Lubello, D.; Cavalli, R. Comparison of biomass feedstock supply and demand in Northeast Italy. Biomass Bioenergy. 2011, 35, 3309-3317. [CrossRef]

2. Marchi, M.; Paletto, A.; Cantiani, P.; Bianchetto, E.; De Meo, I. Comparing thinning systems effects on ecosystem services provision in black pine (Pinus nigra J.F. Arnold) artificial forests. Forests 2018, 9, 188. [CrossRef]

3. Marchi, E.; Picchio, R.; Spinelli, R.; Verani, S.; Venanzi, R.; Certini, G. Environmental impact assessment of different logging methods in pine forests thinning. Ecol. Eng. 2014, 70, 429-436. [CrossRef]

4. Picchio, R.; Neri, F.; Petrini, E.; Verani, S.; Marchi, E.; Certini, G. Machinery-induced soil compaction in thinning two pine stands in central Italy. For. Ecol. Manag. 2012, 285, 38-43. [CrossRef]

5. Mederski, P.S. A comparison of harvesting productivity and costs in thinning operations with and without midfield. For. Ecol. Manag. 2006, 224, 286-296. [CrossRef]

6. Hurlbert, S.H. Pseudoreplication and the design of ecological field experiments. Ecol. Monogr. 1984, 54, 187-211. [CrossRef]

7. Picchio, R.; Neri, F.; Maesano, M.; Savelli, S.; Sirna, A.; Blasi, S.; Baldini, S.; Marchi, E. Growth effects of thinning damage in a Corsican pine (Pinus laricio Poiret) stand in central Italy. For. Ecol. Manag. 2011, 262, 237-243. [CrossRef]

8. Mederski, P.S.; Bembenek, M.; Karaszewski, Z.; Łacka, A.; Szczepańska-Álvarez, A.; Rosińska, M. Estimating and modelling harvester productivity in pine stands of different ages, densities and thinning intensities. Croat. J. For. Eng. 2016, 37, 27-36.

9. Labelle, E.R.; Bergen, M.; Windisch, J. The effect of quality bucking and automatic bucking on harvesting productivity and product recovery in a pine-dominated stand. Eur. J. For. Res. 2017, 136, 639-652. [CrossRef]

10. Proto, A.R.; Macrì, G.; Visser, R.; Harrill, H.; Russo, D.; Zimbalatti, G. Factors affecting forwarder productivity. Eur. J. For. Res. 2018, 137, 143-151. [CrossRef]

11. Spinelli, R.; Magagnotti, N. Performance and cost of a new mini-forwarder for use in thinning operations. J. For. Res. 2010, 15, 358-364. [CrossRef]

12. Lazdinš, A.; Prindulis, U.; Kalēja, S.; Daugaviete, M.; Zimelis, A. Productivity of Vimek 404 T5 harvester and Vimek 610 forwarder in early thinning. Agron. Res 2016, 14, 475-484. 
13. Manner, J.; Nordfjell, T.; Lindroos, O. Effects of the number of assortments and log concentration on time consumption for forwarding. Silva Fenn. 2013, 47. [CrossRef]

14. Spinelli, R.; Cacot, E.; Michelic, M.; Nestorovski, L.; Mederski, P.; Tolosana, E. Techniques and productivity of coppice harvesting operations in Europe: A meta-analysis of available data. Ann. For. Sci. 2016, 73, 1125-1139. [CrossRef]

15. Labelle, E.R.; Soucy, M.; Cyr, A.; Pelletier, G. Effect of tree form on the productivity of a cut-to-length harvester in a hardwood dominated stand. Croat. J. For. Eng. 2016, 37, 175-183.

16. Visser, R.; Spinelli, R. Determining the shape of the productivity function for mechanized felling and felling-processing. J. For. Res. 2012, 17, 397-402. [CrossRef]

17. Ackerman, P.; Martin, C.; Brewer, J.; Ackerman, S. Effect of slope on productivity and cost of Eucalyptus pulpwood harvesting using single-grip purpose-built and excavator-based harvesters. Int. J. For. Eng. 2018, 30, 1-9. [CrossRef]

18. Kulak, D.; Barszcz, A. The impact of selected skidding techniques on soil damage in beech-fir stands. Sylwan 2008, 12, 20-28.

19. Marchi, E.; Picchio, R.; Mederski, P.S.; Vusić, D.; Perugini, M.; Venanzi, R. Impact of silvicultural treatment and forest operation on soil and regeneration in Mediterranean Turkey oak (Quercus cerris L.) coppice with standards. Ecol. Eng. 2016, 95, 475-484. [CrossRef]

20. Cambi, M.; Giannetti, F.; Bottalico, F.; Travaglini, D.; Nordfjell, T.; Chirici, G.; Marchi, E. Estimating machine impact on strip roads via close-range photogrammetry and soil, parameters: A case study in central Italy. iForest 2018, 11, 148-154. [CrossRef]

21. Cambi, M.; Mariotti, B.; Fabiano, F.; Maltoni, A.; Tani, A.; Foderi, C.; Laschi, A.; Marchi, E. Early response of Quercus robur seedlings to soil compaction following germination. Land Degrad. Dev. 2018, 29, 916-925. [CrossRef]

22. Kulak, D.; Stańczykiewicz, A.; Szewczyk, G.; Lubera, A.; Strojny, T. Factors affecting the changes in penetration resistance of forest soils during timber harvesting. Sylwan 2015, 159, 318-325.

23. Sowa, J.; Kulak, D. Probability of occurrence of soil disturbances during timber harvesting. Croat. J. For. Eng. 2008, 29, 29-39.

24. Picchio, R.; Magagnotti, N.; Sirna, A.; Spinelli, R. Improved winching technique to reduce logging damage. Ecol. Eng. 2012, 47, 83-86. [CrossRef]

25. Bembenek, M.; Giefing, D.F.; Karaszewski, Z.; Mederski, P.S.; Szczepańska-Álvarez, A. Tree damage in lowland spruce stands caused by early thinnings. Sylwan 2013, 157, 747-753.

26. Bembenek, M.; Giefing, D.F.; Karaszewski, Z.; Mederski, P.S.; Szczepańska-Álvarez, A. Tree damage in lowland spruce stands because of late thinning. Sylwan 2013, 157, 892-898.

27. Bakinowska, E.; Mederski, P.S.; Szczepańska-Álvarez, A.; Karaszewski, Z.; Bembenek, M. The parallel application of two probability models, logit and probit, for the accurate analysis of spruce timber damage due to thinning operations. Drewno 2016, 59, 49-59.

28. Tavankar, F.; Picchio, R.; Nikooy, M.; Lo Monaco, A.; Venanzi, R.; Iranparast Bodaghi, A. Healing rate of logging wounds on broadleaf trees in Hyrcanian forest with some technological implications. Drewno 2017, 60, 65-80.

29. Marchi, E.; Chung, W.; Visser, R.; Abbas, D.; Nordfjell, T.; Mederski, P.S.; McEwan, A.; Brink, M.; Laschi, A. Sustainable Forest Operations (SFO): A new paradigm in a changing world and climate. Sci. Total Environ. 2018, 634, 1385-1397. [CrossRef] [PubMed]

30. Mederski, P.S.; Karaszewski, Z.; Rosińska, M.; Bembenek, M. Dynamics of harvester fleet change in Poland and factors determining machine occurrence. Sylwan 2016, 160, 795-804.

31. Moskalik, T.; Borz, S.A.; Dvořák, J.; Ferencik, M.; Glushkov, S.; Muiste, P.; Lazdiňš, A.; Styranivsky, O. Timber harvesting methods in Eastern European countries: A review. Croat. J. For. Eng. 2017, 38, 231-241.

32. Spinelli, R.; Magagnotti, N.; Schweier, J. Trends and perspectives in coppice harvesting. Croat. J. For. Eng. 2017, 38, 219-230.

(C) 2018 by the authors. Licensee MDPI, Basel, Switzerland. This article is an open access article distributed under the terms and conditions of the Creative Commons Attribution (CC BY) license (http:/ / creativecommons.org/licenses/by/4.0/). 